\title{
Molecular Markers of Neuronal Subpopulations in Layers 4, 5, and 6 of Cat Primary Visual Cortex
}

\author{
Y. Arimatsu, ${ }^{a}$ J. R. Naegele, and C. J. Barnstable \\ Laboratory of Neurobiology, The Rockefeller University, New York, New York 10021
}

\begin{abstract}
Cat primary visual cortex has been used as an immunogen to produce monoclonal antibodies that detect subpopulations of neurons. When tested by immunofluorescence on tissue sections of areas 17 and 18, 2 of these antibodies, VC1.1 and VC5.1, outlined a rare subpopulation of neurons located mainly in layer 4 but also in layers 5 and 6 . Doublelabeling immunofluorescence experiments in area 17 revealed that all VC1.1-reactive cells were also VC5.1-reactive and $83 \%$ of VC5.1-reactive cells were VC1.1-reactive, suggesting that the antibodies were reacting with the same subpopulation of cells. Both antibodies labeled similar or identical subpopulations of cells in other areas of the cat CNS, including the superior colliculus, parts of hippocampus, cerebellar deep nuclei, and rostral spinal cord. Neither antibody labeled cell bodies in the lateral geniculate nucleus. In the retina, VC1.1 labeled cell bodies and processes of some horizontal and amacrine celis, whereas VC5.1 labeled only ganglion cell axons. In the cerebellar cortex, the most prominent labeling of VC1.1 was of Purkinje cells, whereas that of VC5.1 was of Lugaro cells. Immunoblotting analyses of cat cortical homogenates demonstrated that VC1.1 recognized a major polypeptide band of $M_{\mathrm{r}}$ 95,000105,000 and additional bands of $M_{r} 145,000$ and $M_{r} 170,000$. vC5.1 recognized bands of $M_{r} 97,000$ and $M_{r} 150,000$. Subcellular fractionation and extraction studies showed that the VC1.1 antigens were integral membrane proteins preferentially located in a synaptosomal plasma membrane fraction. The VC5.1 antigens were preferentially located in a soluble cytoplasmic or extracellular fraction. The results indicate that antibodies VC1.1 and VC5.1 recognize unique epitopes in the cat CNS and define a previously unrecognized subpopulation of cells in cat visual cortex.
\end{abstract}

Neuronal circuits of cerebral cortex contain a wide variety of cell classes arranged in characteristic radial and tangential patterns. Morphological distinctions between cortical cell classes have been made on the basis of Golgi staining (reviewed extensively in Peters and Jones, 1984). Additional characterization of cortical circuitry has been made by correlating the electro-

\footnotetext{
Received June 24, 1986; revised Sept. 29, 1986; accepted Oct. 24, 1986.

This work was supported by NIH Grants EY05793, EY05206, and a Senator Jacob Javits Center of Excellence in Neuroscience Grant (NS22789). C.J.B. is an Alfred P. Sloan Research Fellow. We thank G. Szebenyi and P. Schwartz for technical assistance, P. Peirce for photography, and Torsten Wiesel for advice and encouragement.

Correspondence should be addressed to Dr. Colin J. Barnstable at the above address.

a Present address: Department of Neuroscience, Mitsubishi-Kasei Institute of Life Sciences, 11 Minamiooya, Machida-shi, Tokyo 194, Japan.

Copyright (C) 1987 Society for Neuroscience $0270-6474 / 87 / 041250-14 \$ 02.00 / 0$
}

physiological response properties of single cells with their characteristic dendritic and axonal arborization patterns using intracellular dye or enzyme injections (Kelly and Van Essen, 1974; Gilbert and Wiesel, 1979; Lin et al., 1979; Somogyi et al., 1979).

A further step in the identification of structural elements of cortical circuits has been made using biochemical and immunological methods. I Jigh-affinity uptake of radiolabeled neurotransmitters followed by autoradiography has been used to reveal subpopulations of cells in cerebral cortex (Neal and Iversen, 1969; Hökfelt and Ljungdal, 1972; Iversen and Bloom 1972; Baughman and Gilbert, 1981; reviewed in Streit, 1984). Antisera against particular neuroactive substances or neurotransmitter-synthesizing enzymes have also been used to reveal the distribution of different transmitter- or neuropeptide-containing cell bodies and synaptic terminals in the cerebral cortex (Parnavelas and McDonald, 1983; Houser et al., 1983; Emson and Hunt, 1984).

It is clear that the above methods alone cannot give a complete representation of the functional complexity in any given cortical area. It is likely that some aspects of this complexity are reflected in the heterogeneity of expression of cell-surface molecules. These molecules can now be detected by developing monoclonal antibodies against previously unknown or impure antigens and thus producing probes that can reveal cortical heterogeneity and define its molecular basis.

Monoclonal antibodies have already defined a variety of neural molecules, including some that are expressed on subclasses of cells or synapses. In the retina, for example, antibodies have been produced against each of the major subclasses of neuronal and glial cells (Barnstable, 1980; Barnstable et al., 1983, 1985). In other regions of the CNS, monoclonal antibodies have also been used to identify neuronal subsets (Hawkes et al., 1982; McKay and Hockfield, 1982; Sternberger et al., 1982; Wood et al., 1982; Hockfield and McKay, 1983; Kushner, 1984). One conclusion from a number of immunological studies in both vertebrates and invertebrates has been that some of the antibodies recognize groups of cells that are related by function rather than by broader morphological or neurochemical criteria (Zipser and McKay, 1981; Hockfield et al., 1983; Levitt, 1984; Barnstable, 1985; Akagawa and Barnstable, 1986).

We have used material from cat area 17 as an immunogen to generate monoclonal antibodies that can identify new anatomical features and cell types in visual cortex. From the panel of antibodies that were obtained, 2, VC1.1 and VC5.1, recognize a rare population of visual cortical neurons. In this study we describe the labeling patterns given by these antibodies in area 17 and other selected areas of the CNS, as well as some biochemical properties of the antigens recognized. Our findings describe a novel feature of cortical organization defined by the 


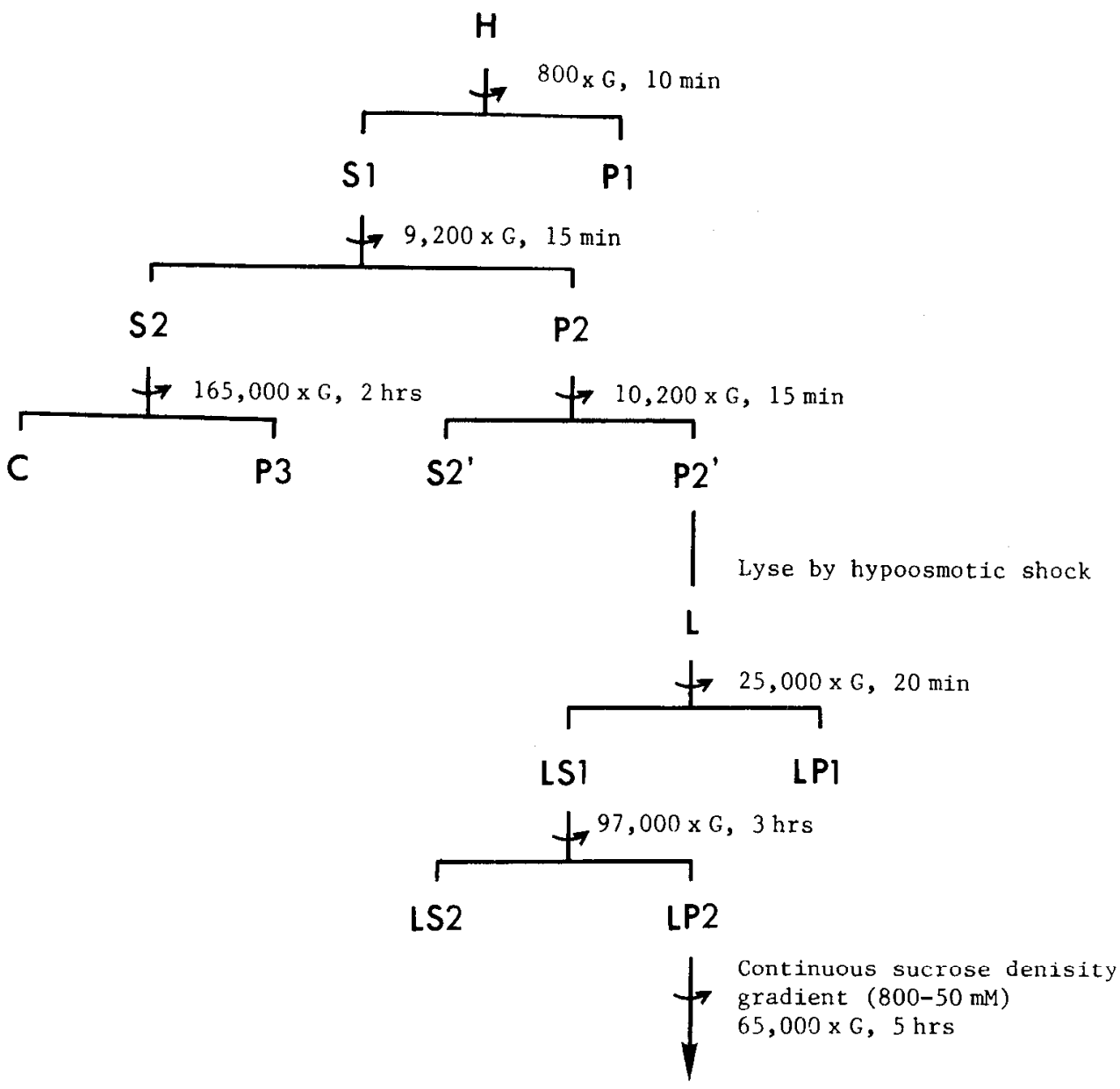

Figure 1. Procedure for subcellular fractionation of cat cortical tissue. localization of antigens VC1.1 and VC5.1. Part of this work has previously been presented in abstract form (Arimatsu et al., 1985).

\section{Materials and Methods}

Antibody production. I wo female BALB/c mice were immunized with homogenates of cat area 17. The first immunization was intraperitoneal, with complete Freund's adjuvant; subsequent intraperitoneal injections used incomplete Freund's adjuvant, and the final injection was intravenous with the antigen in isotonic saline. One mouse received unfixed homogenate ( $20 \mathrm{mg}$ wet weight) on days 0,28 , and 84 . The other received homogenate $(20 \mathrm{mg}$ wet weight) fixed with $0.5 \%$ paraformaldehyde, as previously described (Fekete and Barnstable, 1983) on days $0,28,84$, and 224 . Four days after the final injection, the spleens were removed and approximately $2 \times 10^{8}$ cells from each were fused with $2 \times 10^{7} \mathrm{P} 3-\mathrm{NSI} / \mathrm{l}-\mathrm{Ag} 4-1$ plasmacytoma cells, as described elsewhere (Kohler and Milstein, 1975; Barnstable, 1982). Hybrid cultures were selected in Hypoxanthine-Aminopterin-Thymidine(HAT) medium and culture supernatants of growing colonies were screened by indirect immunofluorescence. Selected hybridomas were recloned at least twice by limiting dilution. Immunoglobulin (Ig) subclass of secreted antibodies was determined with Ouchterlony analysis using subclass-specific antisera (Miles).

Screening and histological characterization of antibodies. Adult cats were deeply anesthetized with pentobarbital and intracardially perfused with PBS and then with 4\% paraformaldehyde in PBS. One hour after the perfusion, the brains were removed, blocked, and postfixed in the same fixative for $5 \mathrm{hr}$ at $4^{\circ} \mathrm{C}$. The tissues were immersed in PBS containing $30 \%$ sucrose and embedded in O.C.T. compound (Miles). Cryostat sections were cut at $12 \mu \mathrm{m}$, mounted on gelatin-coated glass slides, and stored at $-20^{\circ} \mathrm{C}$ until use. Indirect immunofluorescence labeling of sections was carried out as described previously (Barnstable, 1982). To identify laminac of the visual cortex, selected sections were stained for cytochrome oxidase activity (Wong-Riley, 1979; Price, 1985). The borders between cortical areas 17,18 , and 19 were determined by the cytoarchitectonic criteria of Otsuka and Hassler (1962).

Two-color immunofluorescence labeling with $\operatorname{Ig} G$ and IgM. In order to examine the possible colocalization of antigenic sites that were labeled with mouse monoclonal IgG or IgM, double immunofluorescence labeling experiments were performed. Sections were incubated sequentially with (1) a monoclonal antibody of $\mathrm{IgG}$, (2) fluorescein isothiocyanate (FITC)-conjugated goat anti-mouse Fc (Miles), (3) another mouse monoclonal antibody of IgM, and (4) rhodamine isothiocyanate (RITC)conjugated goat anti-mouse IgM (Cappel; $\mu$-chain-specific). After washing in PBS, sections were coverslipped in a mounting medium containing $0.1 \%$ paraphenylenediamine (Sigma) in PBS, pH 9.0, to retard fading of FITC fluorescence (Valnes and Brandtzaeg, 1985), and viewed using a combination of filters for FITC and RITC. Control sections were incubated with normal culture medium containing $10 \%$ fetal calf serum instead of IgG (step 1) or instead of IgM (step 3).

Subcellular fractionation. Subcellular fractionation of the cat cortical tissue was carried out essentially as described by Huttner et al. (1983) for rat cortex. The procedure is shown diagrammatically in Figure 1. An adult cat was killed under deep anesthesia by pentobarbital. The brain was removed into ice-cold buffered sucrose ( $320 \mathrm{~mm}$ sucrose, 4 mM HEPES- $\left.\mathrm{NaOH}, \mathrm{pH} 7.4,0.05 \% \mathrm{NaN}_{3}\right)$. The cerebral cortex $(14 \mathrm{gm}$ wet weight) was dissected out from other portions of the brain and cut into small pieces. After removal of most of the white matter, the tissue was homogenized with $80 \mathrm{ml}$ of buffered sucrose in a glass-Teflon homogenizer. The homogenate was centrifuged at $800 \times g$ for $10 \mathrm{~min}$. The pellet (P1) was discardcd. The supernatant (S1) was collected and centrifuged at $9200 \times g$ for $15 \mathrm{~min}$. The resulting supernatant (S2) was centrifuged at $165,000 \times g$ for $2 \mathrm{hr}$ to yield a pellet (P3) and a cytosol fraction (C). The pellet (P2) obtained by centrifuging the $\mathrm{S} 1$ fraction was washed by suspension in $50 \mathrm{ml}$ of buffered sucrose and centrifu- 


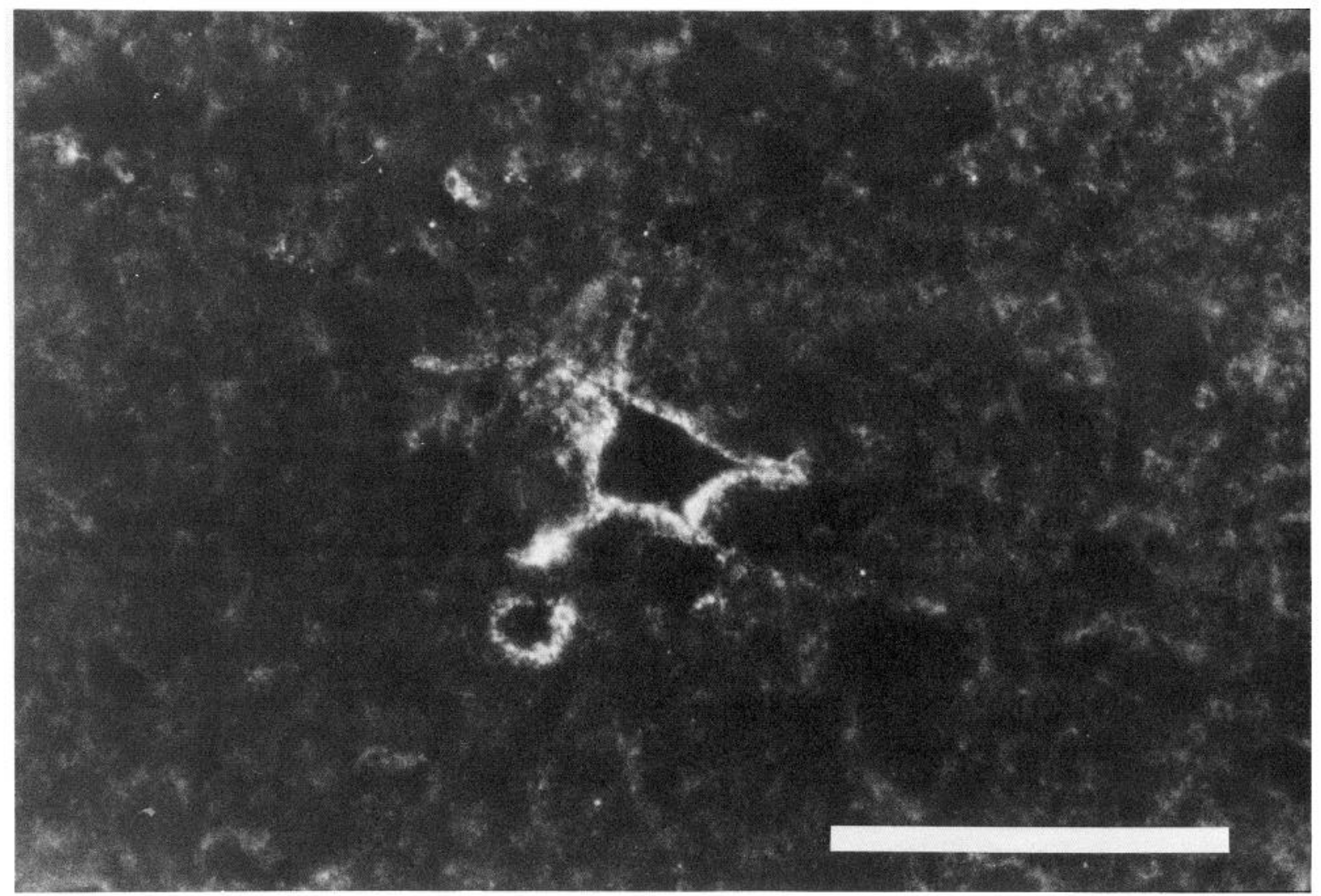

Figure 2. Immunofluorescence photomicrograph of VC1.1 in layer 4 of caudal area 17. Sagittal section. Scale, $100 \mu \mathrm{m}$.

gation at $10,200 \times g$ for $15 \mathrm{~min}$. The washed pellet $\left(\mathbf{P} 2^{\prime}\right)$ was resuspended in $15 \mathrm{ml}$ of buffered sucrose. The synaptosome suspension was lysed by homogenization with $135 \mathrm{ml}$ of $\mathrm{H}_{2} \mathrm{O}$. The resulting $\mathrm{P} 2$ ' lysate (L) was adjusted to $8 \mathrm{~mm}$ HEPES, pH 7.4, incubated for $30 \mathrm{~min}$ and centrifuged at $25,000 \times g$ for $20 \mathrm{~min}$. The pellet (LP1) was removed and the supernatant (LS1) was centrifuged at $97,000 \times g$ for $3 \mathrm{hr}$ to yield a supernatant (LS2) and a pellet (LP2). The LP2 fraction was resuspended in $4 \mathrm{ml}$ of $40 \mathrm{~mm}$ sucrose by homogenization. Three milliliters of the suspension was layered on a linear sucrose gradient made from $16 \mathrm{ml}$ of $800 \mathrm{~mm}$ sucrose and $14 \mathrm{ml}$ of $50 \mathrm{~mm}$ sucrose, centrifuged in a swinging bucket rotor at $65,000 \times g$ for $5 \mathrm{hr}$, and the gradient was collected in $1.1 \mathrm{ml}$ fractions through the bottom of the tube.

Immunoblotting. Aliquots of subcellular fractions of the cat cortex were applied to $7.5 \%$ SDS-polyacrylamide gels and electrophoresed using the buffer system of Laemmli (1970) in the presence of 2-mercaptoethanol. After electrophoresis, proteins were electrophoretically blotted onto nitrocellulose and labeled with antibodies, as described previously (Towbin et al., 1979; Fekete and Barnstable, 1983). The labeled proteins were detected using HRP-conjugated anti-mouse IgG $(\mathrm{H}+\mathrm{L}$; Cappel). The apparent molecular weight of each stained band was determined by comparison with the migration of standard proteins and was derived from at least 3 separate experiments. Aliquots from the sucrose gradient-fractionated LP2 fraction were assayed on separate blots for the presence of $\mathrm{VCl} 1$.1 antigen and the synaptic vesicle protein p38. The p38 antigen was detected using monoclonal antibody $7.1 \mathrm{~b}$ (a gift from R. Jahn and P. Greengard, Rockefeller University), whose specificity has already been documented (Jahn et al., 1985). Direct comparison of the molecular weights of the VC1.1 and VC5.1 determinants was facilitated by running aliquots of the same subcellular fractions on identical gels. Protein concentrations were determined by the method of Lowry et al. (1951).

Solubilization of antigens. The LP1 and P3 fractions from the cortical homogenate were used. Each fraction was washed by adding an excess of $10 \mathrm{~mm}$ Tris- $\mathrm{HCl}, \mathrm{pH} 8.0$, and centrifuging at $164,000 \times \mathrm{g}$ for $2 \mathrm{hr}$. The washed pellet was resuspended in the same hypotonic buffer by homogenization and frozen at $-80^{\circ} \mathrm{C}$ (overnight) to ensure hypotonic lysis. Aliquots containing $1 \mathrm{mg}$ protein were incubated at $4^{\circ} \mathrm{C}$ for $1 \mathrm{hr}$ in 1 of the following solutions in a final volume of $1 \mathrm{ml}$ : (1) $10 \mathrm{~mm}$ Tris- $\mathrm{HCl}, \mathrm{pH} 8.0$; (2) $1 \mathrm{M} \mathrm{NaCl}$ in $10 \mathrm{~mm}$ Tris-HCl, $\mathrm{pH} 8.0$; (3) $3 \mathrm{M}$ $\mathrm{NaCl}$ in $10 \mathrm{~mm}$ Tris- $\mathrm{HCl}, \mathrm{pH} 8.0$; (4) $10 \mathrm{~mm}$ Tris- $\mathrm{HCl}, \mathrm{pH} 3.0$; (5) 10 mMTris- $\mathrm{HCl}$, pH 11.5 ; (6) $3 \%$ Triton X-100 in $10 \mathrm{~mm}$ Tris- $\mathrm{HCl}, \mathrm{pH}$ 8.0 ; (7) $2 \%$ deoxycholate in $10 \mathrm{~mm}$ Tris- $\mathrm{HCl}, \mathrm{pH} 8.0$. After incubation, the samples were centrifuged at $164,000 \times g$ for $2 \mathrm{hr}$. The resultant pellets and supernatants were analyzed by immunoblotting, as described above.

\section{Results}

From the 2 fusions carried out, 1125 hybrid colonies were derived. These were screened by indirect immunofluorescence of fixed tissue sections of cat area 17. Two hundred and seventeen colonies (19\%) showed positive immunoreactivity. Most of these showed some selectivity in labeling, although few were as specific as the 2 described here. Antibody VC1.1 was derived by immunization with unfixed homogenate, and antibody VC5.1 by immunization with paraformaldehyde-fixed material. Ouchterlony double-diffusion against subclass-specific antisera defined VC1.1 as an IgM and VC5.1 as an $\operatorname{IgG}_{1}$.

\section{Immunofluorescence localization in area 17}

Antibody VC1.1. Monoclonal antibody VC1.1 outlined neuronal cell bodies and proximal portions of dendrites (Fig. 2). The labeling was distributed around cell bodies in a discontinuous or fenestrated pattern. The neurons outlined by VC1.1 were mainly in layer 4 , but smaller numbers were also found in layers 5 and 6 (Fig. 3). Some of the labeled cells were identified as multipolar nonpyramidal cells, but the exact class of the others could not be identified because of incomplete dendritic labeling. 


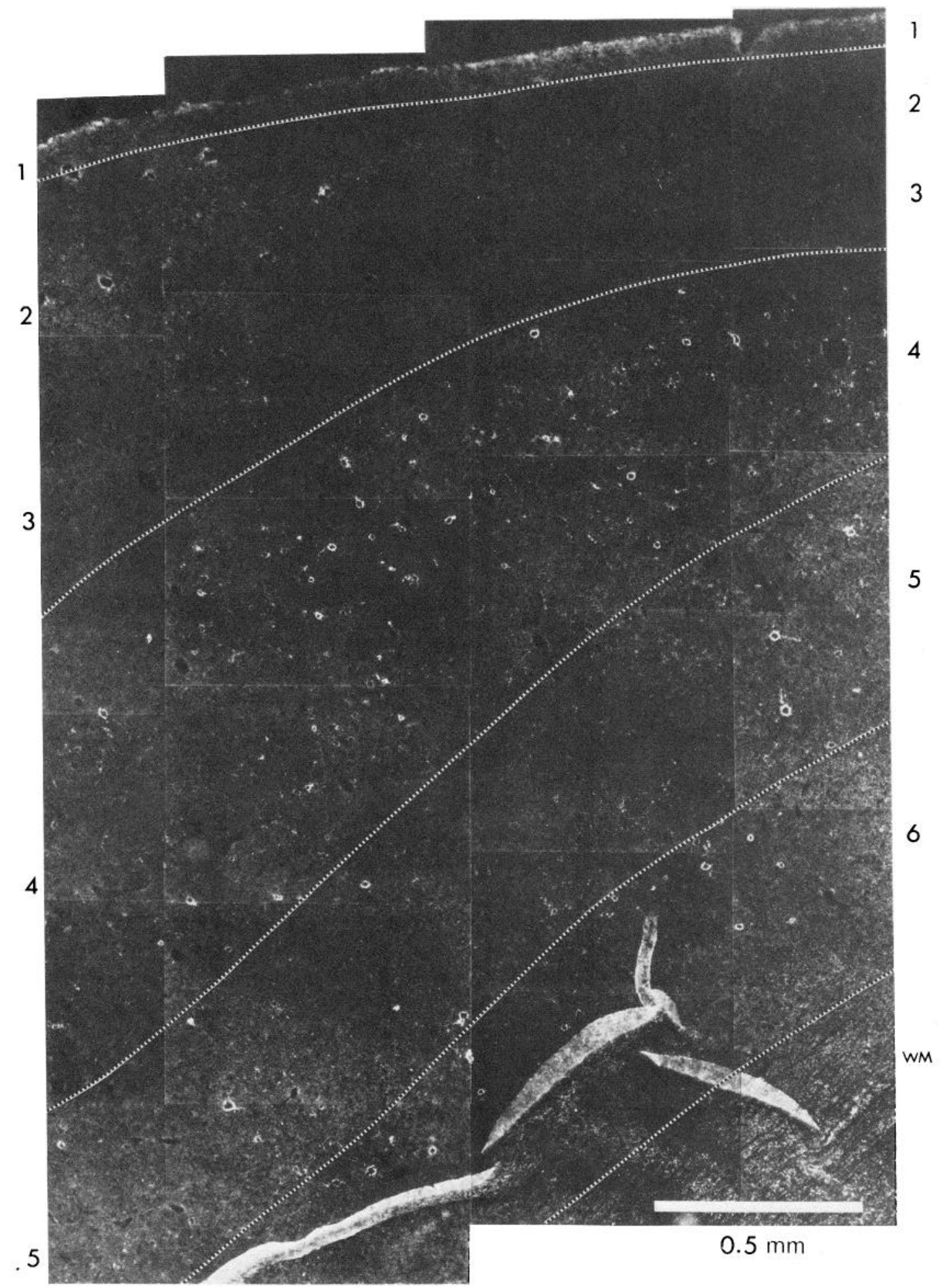

6

Figure 3. Photomontage of immunofluorescence for VC1.1 in caudal area 17. The section was cut through an oblique plane against the pia mater. Cortical layers (indicated by numerals) were determined by the staining pattern for cytochrome oxidase activity originally described by WongRiley (1979) (see Fig. 4C). Artifacts due to folding of the section are seen in layer 6 and white matter $(W M)$.

In addition to outlining some neurons strongly, VC1.1 showed a much less distinct labeling of neuropil.

Antibody VC5.1. Monoclonal antibody VC5.1 also outlined subpopulations of neurons in area 17. Although labeling appeared more continuous than with VC1.1 and tended to extend further along the dendrites, the laminar distribution of VC5.1 labeling in this area was the same as that of VC1.1, with most labeled cells in layer 4 and a few in layers 5 and 6 (Fig. $4 A$ ). Some of the VC5.1-positive cells were identified as nonpyramidal by their well-labeled dendritic arbors, which most closely 

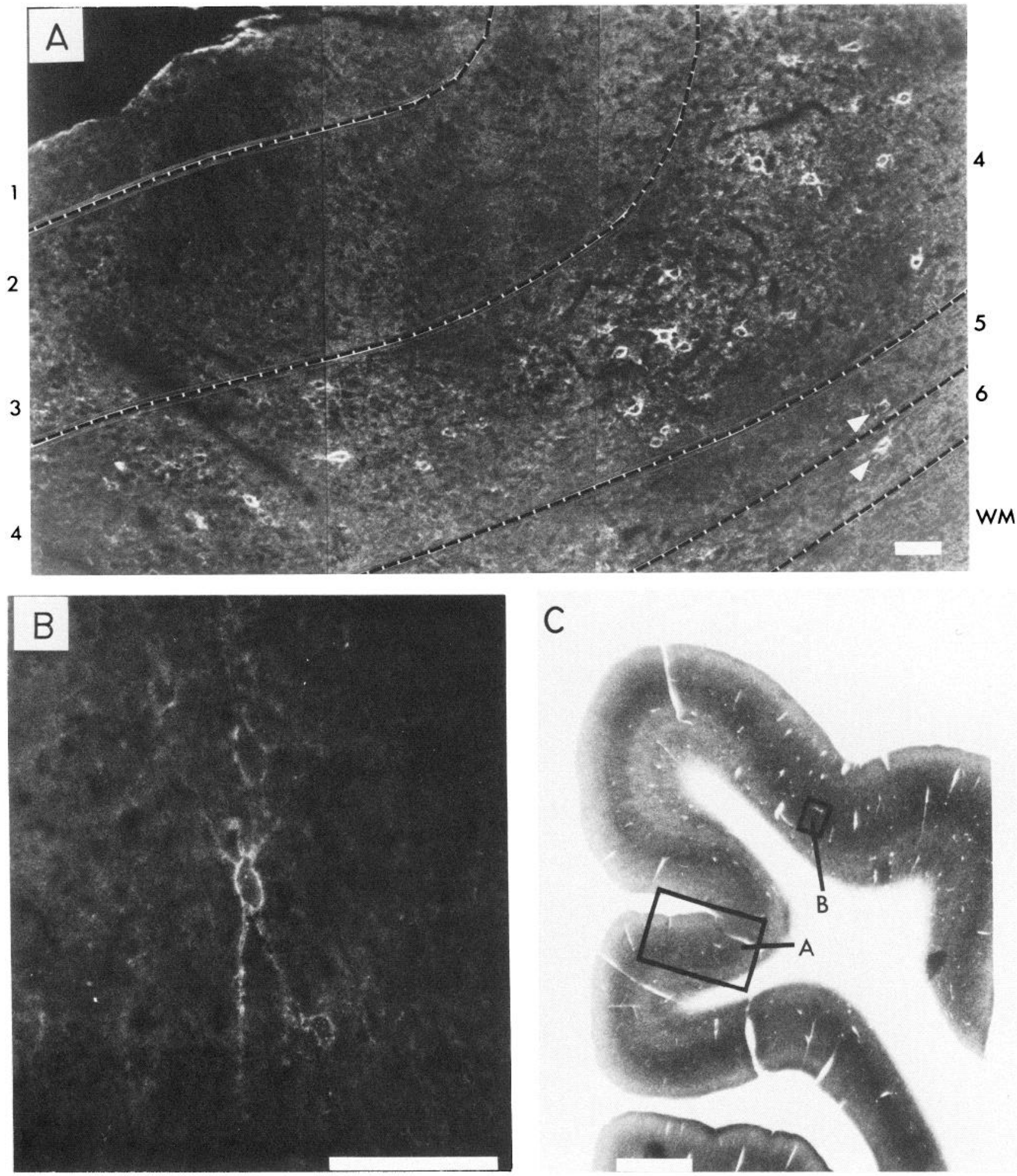

Figure 4. A, Photomontage of immunofluorescence for VC5.1 in a frontal section of rostral area 17. Cortical layers (indicated by numerals) were determined by the staining pattern for cytochrome oxidase activity. $B$, Immunofluorescence photomicrograph for VC5.1 in area 18 in the same section as $A$. C , Cytochrome oxidase staining in a section adjacent to that shown in $A$ and $B$. In area 17, layer 4 is distinctly identified by heavy staining for the enzyme, as described previously (Wong-Riley, 1979; Price; 1985). Areas corresponding to $A$ and $B$ are shown by rectangles. Scale in $A$ and $B, 100 \mu \mathrm{m}$. Scale in $C, 1 \mathrm{~mm}$. 

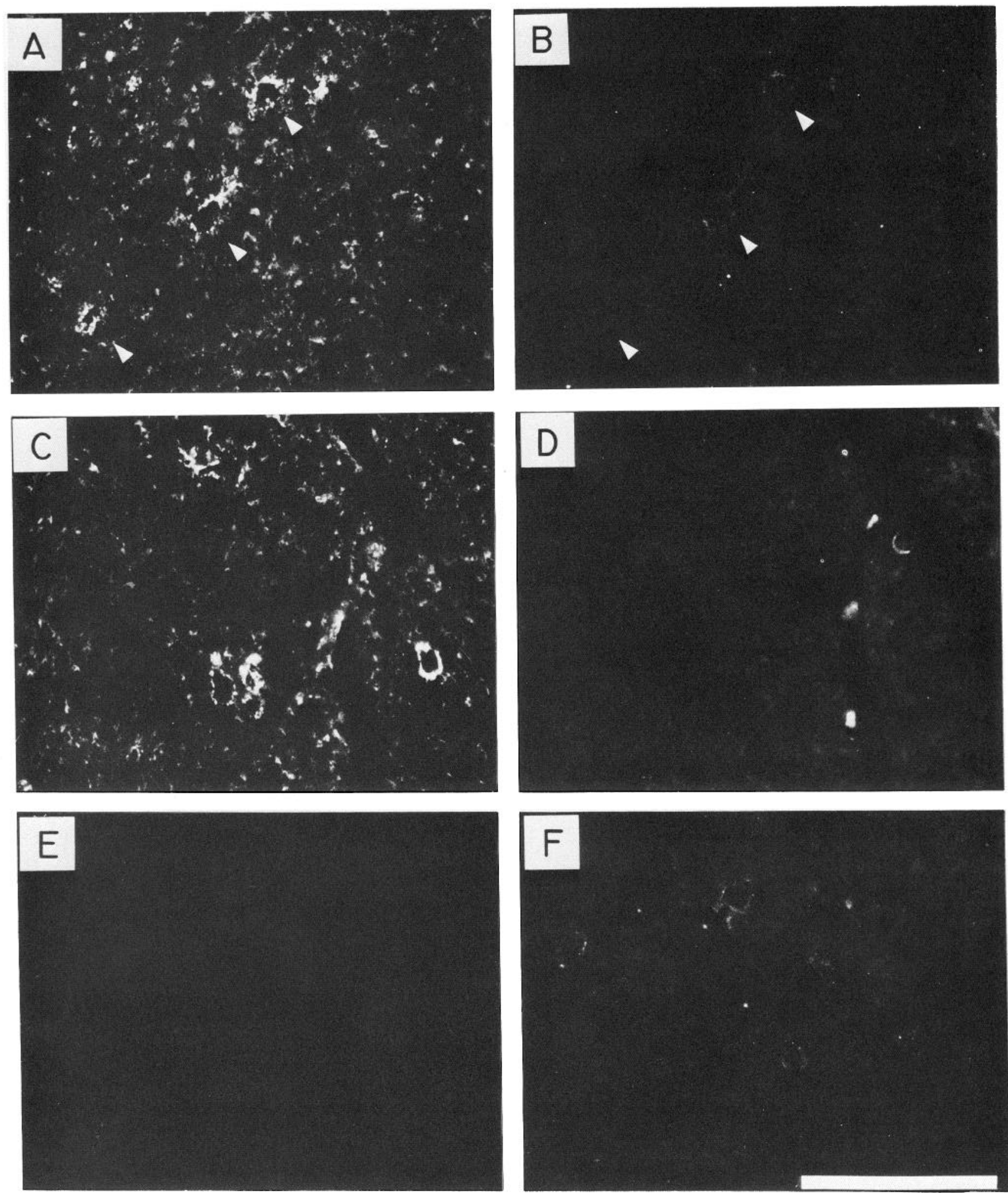

Figure 5. A, B, Double-immunofluorescence labeling for VC1.1 and VC5.1. A frontal section through rostral area 17 was incubated sequentially with VC5.1 ( $\left.\mathrm{IgG}_{1}\right)$. FITC-conjugated goat anti-mouse Fc, VC1.1 (IgM), and RITC-conjugated goat anti-mouse IgM. Photographs were taken using filters for RITC $(A)$ or FITC $(B)$. Note that all VC1.1-positive cells (arrowheads in $A$ ) are also positive for VC5.1 (arrowheads in $B$ ). $C-F$, Control section incubated with VC1.1 but not VC5.1 $(C, D)$, or with VC5.1 but not VC1.1 $(E, F)$. Photographs were taken as above $(C$ and $E$, RITC filter; $D$ and $F$, FITC filter). Note the absence of specific FITC and RITC fluorescence in $D$ and $E$, respectively. Scale, $100 \mu \mathrm{m}$. 

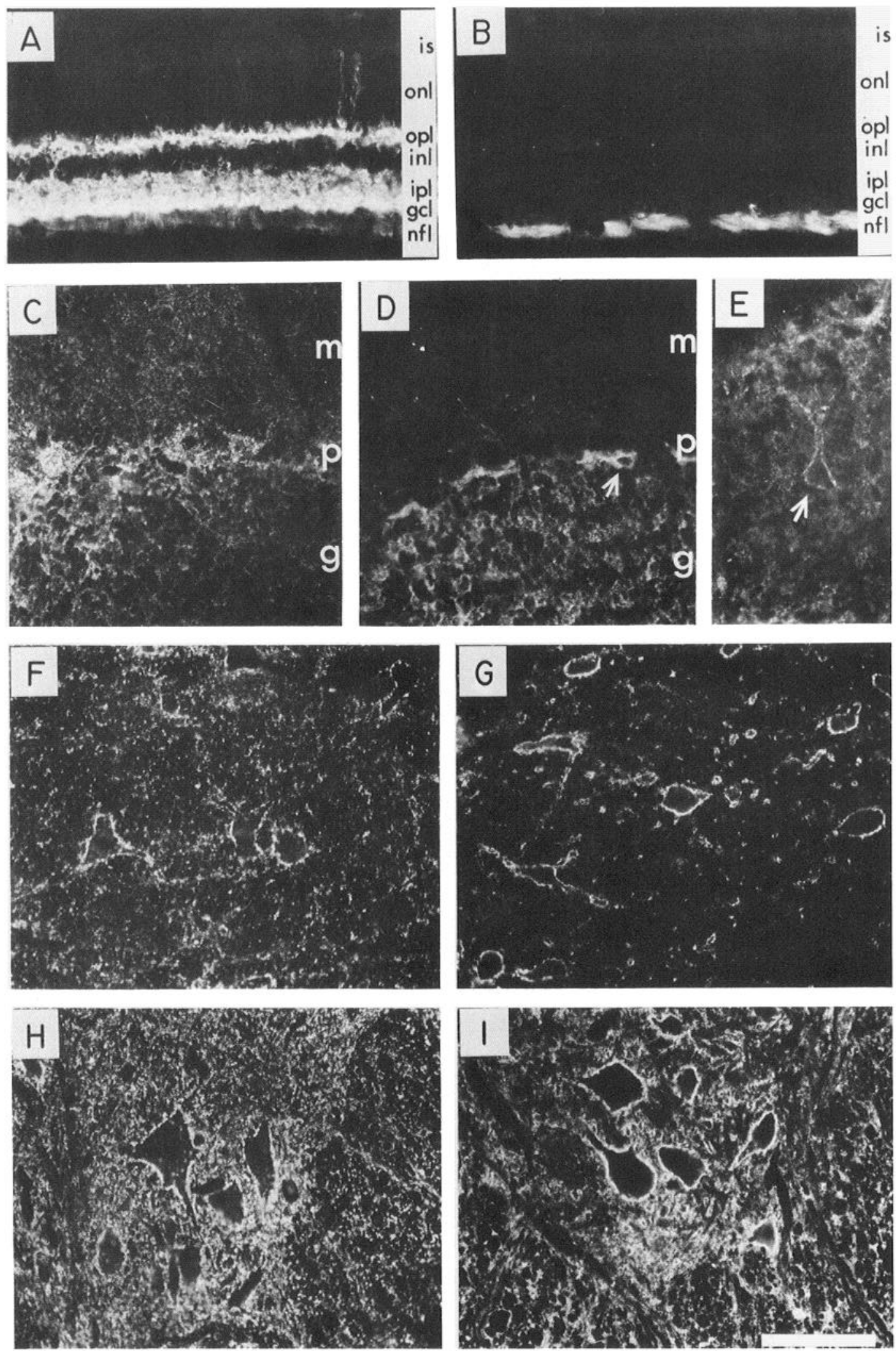

Figure 6. Immunofluorescence photomicrographs for VC1.1 and VC5.1 in various CNS regions. $A, B$, Retina labeled with VC1.1 $(A)$ and VC5.1 (B). is, Photoreceptor inner segment; onl, outer nuclear layer; opl, outer plexiform layer; inl, inner nuclear layer; ipl, inner plexiform layer; $g c l$, ganglion cell layer; $n f l$, optic nerve fiber layer. $C, D, E$, Cerebellar cortex labeled with VC1.1 $(C)$ and VC5.1 $(D, E)$. $m$, Molecular layer; $p$, Purkinje cell layer; $g$, granule cell layer; arrow in $D$, Lugaro cell; arrow in $E$, Golgi cell. $F$, $G$, Cerebellar-deep nucleus labeled with VCl.1 $(F)$ and VC5.1 $(G) . H, I$, Spinal cord labeled with VC1.1 and VC5.1. Scale, $100 \mu \mathrm{m}$. 


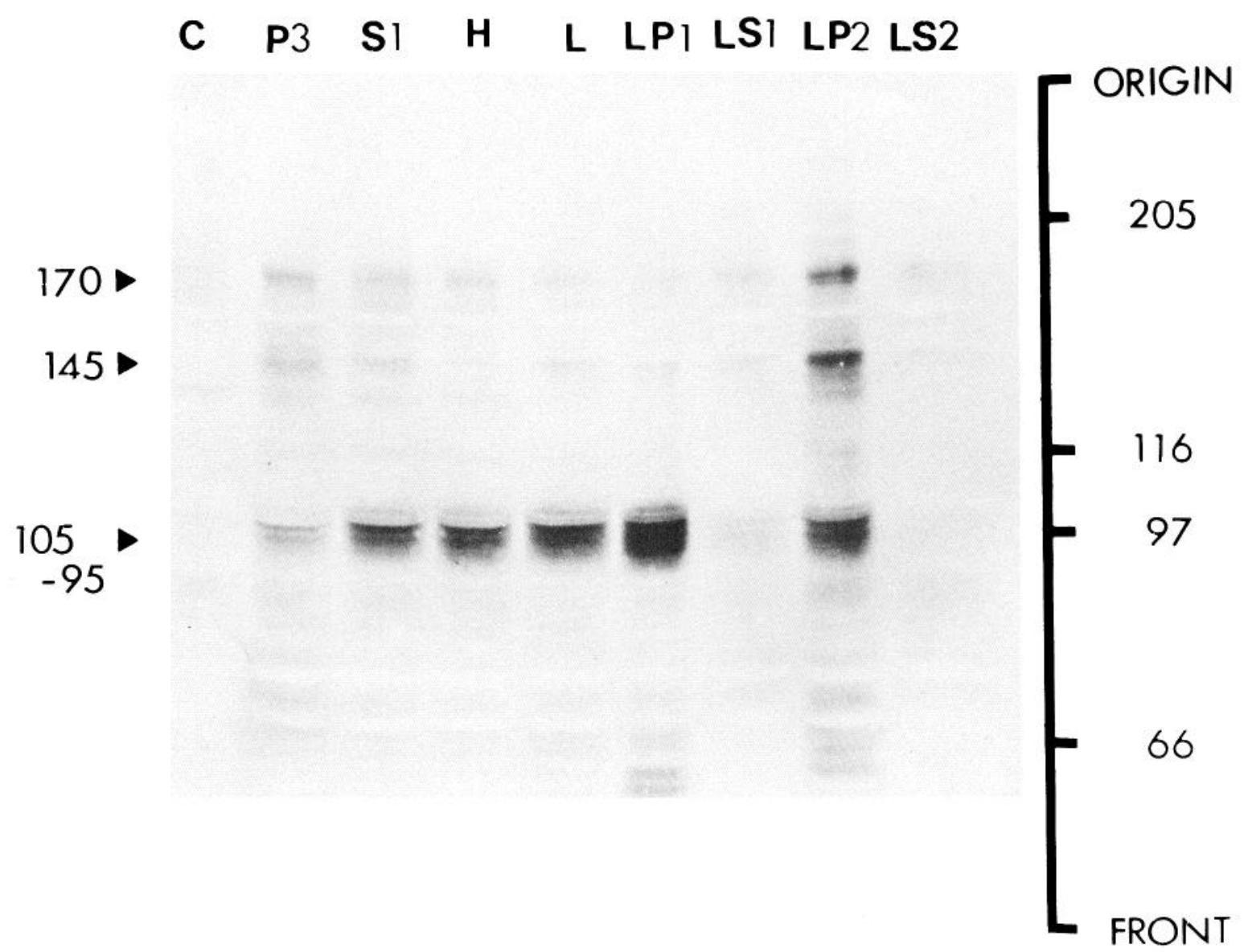

Figure 7. VC1.1 immunoreactivity in various subcellular fractions from cat cortical tissue. Aliquots of riractions containing $50 \mu \mathrm{g}$ protein were electrophoresed, blotted, and stained with VC1.1, as described in the text. Reference proteins indicated on the right are myosin $\left(M_{\mathrm{r}} 205,000\right)$, $\beta$-galactosidase $\left(M_{\mathrm{r}} 116,000\right)$, phosphorylase B $\left(M_{\mathrm{r}} 97,000\right)$, and BSA $\left(M_{\mathrm{r}} 66,000\right)$.

resembled those of multipolar or bitufted cortical interneurons.

Colocalization of VC1.1 and VC5.1 immunofluorescence. Because the labeling patterns given by $\mathrm{VCl} .1$ and $\mathrm{VC} 5.1$ were so similar in area 17, double-labeling experiments were performed to test whether the labeled cell populations were identical. Because $\mathrm{VC} 1.1$ was an IgM and VC5.1 was an $\mathrm{IgG}_{1}$, the antibodies could be distinguished from each other on the same sections using RITC-conjugated anti-mouse IgM for VC1.1 and FITCconjugated anti-mouse Fc for VC5.1.

Within area 17, the great majority of VC5.1-immunoreactive neurons were also immunoreactive to VC1.1 (Fig. 5, A,B). Among 100 immunoreactive neurons counted in 1 section, 83 were labeled by both $\mathrm{VCl} 1.1$ and VC5.1. The remaining 17 neurons were labeled by VC5.1 but not by VC1.1. Control sections incubated with VC1.1 but not VC5.1 showed no specific FITC fluorescence (see Fig. 5, C,D). Similarly, sections incubated with VC5.1, but not VC1.1, showed no specific RITC fluorescence (see Fig. 5, E,F).

\section{Localization of VC1.1 and VC5.1 immunoreactivity in other CNS regions}

In addition to area 17, both antibodies labeled other regions of cat CNS. To further characterize the labeling patterns given by the 2 antibodies, selected regions were examined by indirect immunofluorescence.

In cortical area 18, VC1.1 and VC5.1 labeled subpopulations of neurons within middle and deep layers (see Fig. $4 B$ for VC5.1 labeling). In the superior colliculus, the immunofluorescence for both VCl.1 and VC5.1 outlined subpopulations of neurons against a background of neuropil labeling that was detected in all layers in a nonuniform way. Double-labeling experiments showed that at least some neurons were labeled by both antibodies (data not shown). Neither antibody labeled cell bodies in the lateral geniculate nucleus. In the retina, VC1.1 labeled structures within the inner and outer plexiform layers, and horizontal and amacrine bodies were also clearly outlined in the inner nuclear layer (Fig. 6A). In contrast, VC5.1 did not label plexiform or nuclear layers but did label the optic nerve fiber layer (Fig. 6B).

In the hippocampus, VC1.1 and VC5.1 immunofluorescence outlined subpopulations of granule cells in the dentate gyrus and pyramidal cells in CA2-CA4 (data not shown). The labeling given by the 2 antibodies was very similar. Only very few CA1 pyramidal cells were outlined by either antibody. Some neuropil labeling for VC1.1 and VC5.1 was also observed, although the intensity varied between layers. The neuropil labeling for these antibodies was strong in the hilus of the dentate gyrus, particularly near the granule cell layer.

In the cerebellar cortex, VC1.1 gave punctate labeling in Purkinje cell bodies (Fig. $6 C$ ), whereas VC5.1 outlined Lugaro cells (see Palay and Chan-Palay, 1973, for a general review of Lugaro cells) and labeled structures around the initial axon segment of 


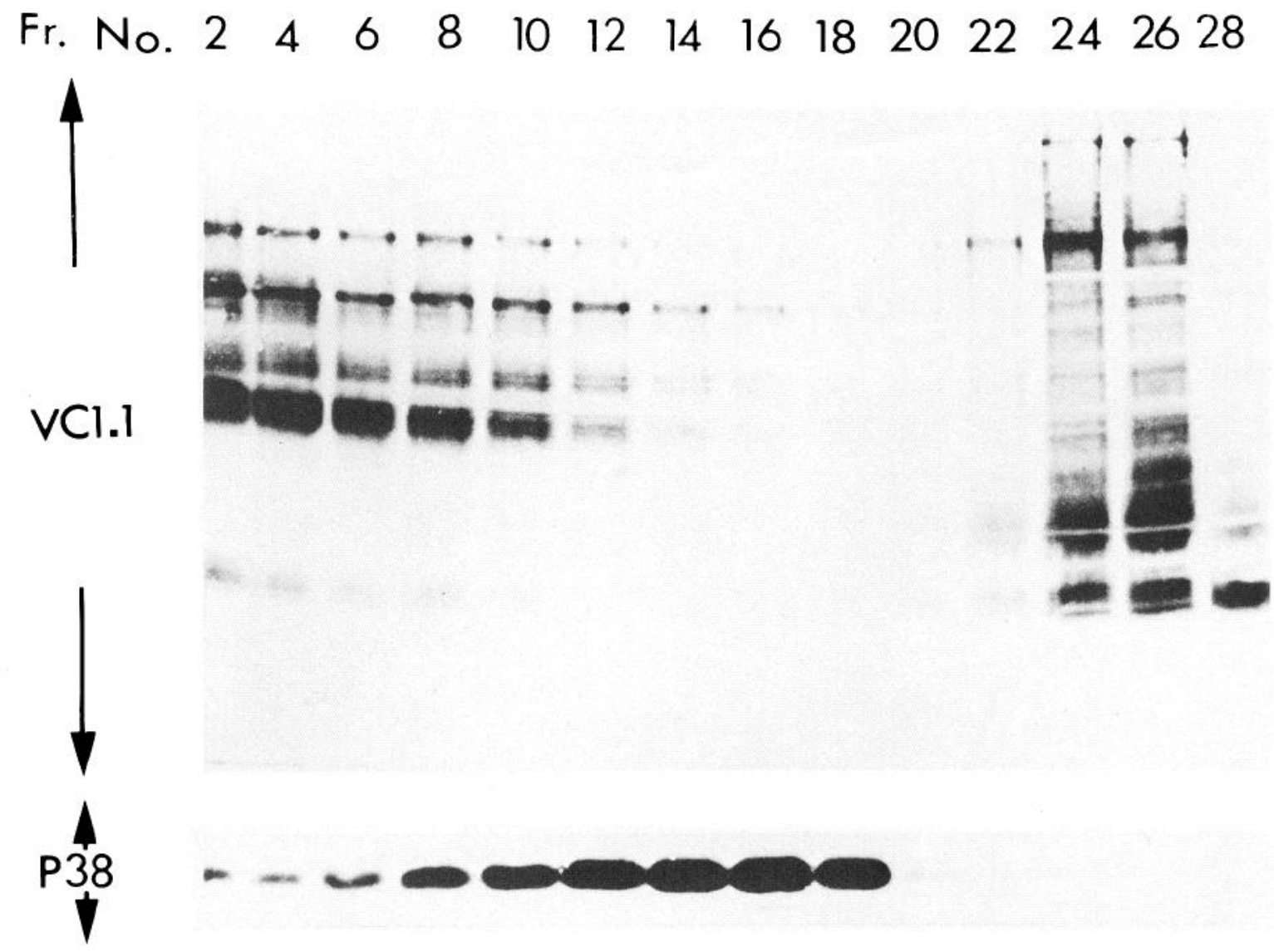

Figure 8. Top, VC1.1 immunoreactivity in fractions after continuous sucrose density-gradient centrifugation of fraction LP2. Aliquots (90 $\mu$ l) of alternate fractions (Fr.) were electrophoresed, blotted, and stained with VC1.1, as described in the text. Bottom, Immunoreactivity for p38, a synaptic vesicle protein, in fractions after continuous sucrose density-gradient centrifugation of fraction LP2. Aliquots ( $75 \mu \mathrm{l})$ were electrophoresed, blotted, and stained with monoclonal antibody 7.1b (a gift from Dr. R. Jahn, The Rockefeller University), as described in the text.

Purkinje cells corresponding to the terminal regions of basket cells (Fig. 6D). Occasionally, VC5.1-positive Golgi cells were observed (Fig. 6E). Both VC1.1 and VC5.1 showed intense labeling around many neurons in cerebellar deep nuclei (Fig. 6, $F, G)$.

In the rostral spinal cord, strong labeling was observed with VC1.1 and VC5.1 around selected neuronal populations, including motor neurons of the ventral horn (Fig. 6, H,I). In the gray matter, both antibodies showed a similar pattern of neuropil labeling. Strong immunofluorescence was observed in the substantia gelatinosa and areas around the central canal. In the white matter, these antibodies labeled structures between myelinated axons (see Fig. 6, $H, I$ ).

\section{Subcellular distribution of VC1.1 and VC5.1 antigens}

The antigens detected by monoclonal antibodies VCl.1 and VC5.1 were characterized by immunoblotting analysis on various subcellular fractions from cat cortex.

Antibody VC1.1. Antibody VC1.1 recognized a major polypeptide band of $M_{\mathrm{r}} 95,000-105,000$ and additional minor bands of $M_{\mathrm{r}} 145,000$ and $M_{\mathrm{r}} 170,000$ in the cortical homogenates (Fig. 7). When these homogenates were fractionated by differential centrifugation, the polypeptide band of $M_{\mathrm{r}} 95,000-105,000$ was the most enriched in the LP1 fraction, a low-speed pellet of a crude synaptosomal lysate. Lower levels of immunoreactivity were found in the microsomal fraction (P3) and the LP2 fraction, a high-speed pellet of the synaptosomal lysate. The cytosol fraction (C) and a high-speed supernatant of the lysate (LS2) had only a low level of immunoreactivity for this band. The minor polypeptide bands of higher molecular weight $\left(M_{\mathrm{r}} 145,000\right.$ and $\left.M_{\mathrm{r}} 170,000\right)$ showed a different fractionation pattern and were localized mainly in the P3 and LP2 fractions.

Reactivities for all 3 polypeptide bands were detected with the LP2 fraction. Because this fraction is known to contain both synaptic membranes and vesicles, these components were separated using a continuous sucrose gradient of $50-800 \mathrm{~mm}$. As shown at the top of Figure 8, reactivity for all 3 bands was found in fractions 2-10, near the bottom of the gradient. Much lower levels of reactivity were found in the middle portions of the gradient (fractions 12-18). These fractions were enriched in synaptic vesicles, which were identified by labeling separate immunoblots of the same fractions for a synaptic vesicle-specific protein, p38 (Jahn et al., 1985) (Fig. 8, bottom). At the top of the gradient (fractions 24-28), reactivity was found in a number of low-molecular-weight bands. Since these were not present in the sample loaded on the gradient (lane LP2 in Fig. 7), they probably represent proteolytic degradation products of sample handling and centrifugation. Similarly, a minor band of molecular weight higher than $M_{\mathrm{r}} 170,000$ was found in fractions 2428 but was not found in the starting LP2 fraction.

Antibody VC5.1. In the initial cortical homogenate, 2 polypeptide bands of $M_{\mathrm{r}} 97,000$ and $M_{\mathrm{r}} 150,000$ were detected by 


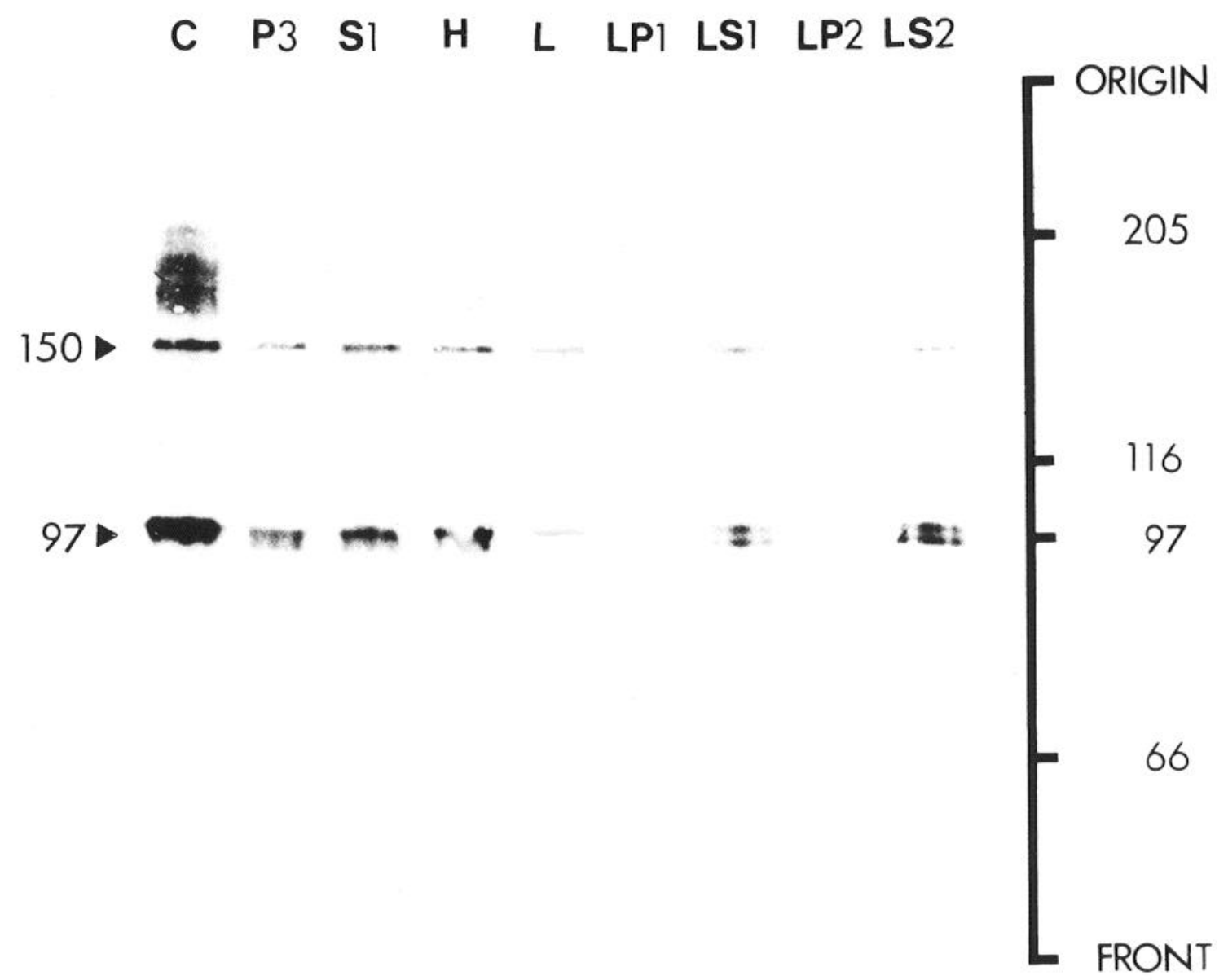

Figure 9. VC5.1 immunoreactivity in various subcellular fractions from cat cortical tissue. Aliquots of fractions containing $120 \mu \mathrm{g}$ of protein were electrophoresed, blotted, and stained with VC5.1, as described in the text. Reference proteins indicated on the right are the same as those indicated for Figure 7.

VC5.1 (Fig. 9). Among the various subcellular fractions derived from the homogenate, the cytosol fraction (C) was most enriched in VC5.1 immunoreactivity, although some reactivity was also found in the microsomal fraction (P3) and the supernatants of synaptosomal lysate (LS1 and LS2).

\section{Solubilization of VC1.1 antigens}

VC1.1 antigens of $M_{\mathrm{r}} 95,000-105,000, M_{\mathrm{r}} 145,000$, and $M_{\mathrm{r}}$ 170,000 were localized in particulate fractions (LP1, LP2, and P3) but not in soluble fractions (C and LS2), which suggests that the antigens were membrane-associated. The nature of the association of these antigens in the LP1 and P3 fractions was characterized by incubating each fraction in buffers of high ionic strength, low or high $\mathrm{pH}$, or in the presence of detergent. As shown in Figure 10, high ionic strength $(1 \mathrm{M} \mathrm{NaCl}$, Fig. 10, lane 2; $3 \mathrm{M} \mathrm{NaCl}$, lane 3) and low or high $\mathrm{pH}(\mathrm{pH} \mathrm{3}$, Fig. 10, lane 4; $\mathrm{pH} 11.5$, lane 5) caused no effective solubilization of these antigens. However, all 3 bands of VCl.1 antigens in both fractions were solubilized very effectively with $2 \%$ deoxycholate (Fig. 10, lane 7) and less effectively with $3 \%$ Triton X-100 (lane 6).

\section{Discussion}

We have used an immunological approach to define new structural features of cat CNS. In area 17, antibodies VC1.1 and VC5.1 each labeled rare subpopulations of neurons, most of which were located in layer 4 , with the remainder in layers 5 and 6. Two-color immunofluorescence labeling of tissue sections from area 17 showed that $83 \%$ of cells labeled with VC5.1 were also labeled with VC1.1. The remaining cells were VC5.1-positive/ $\mathrm{VCl}$.1-negative. Because VCl.1 is an IgM and penetrates tissue less well than VC5.1, which is an IgG, it is likely that the figure of $83 \%$ for double-labeled cells is an underestimate and that the 2 antibodies were recognizing the same population.

In spite of this close similarity in labeling patterns in area 17, the epitopes recognized by VCl.1 and VC5.1 were clearly different. Evidence suggestive of this was the different quality and extent of labeling given by the 2 antibodies. $\mathrm{VCl} .1$ gave a punctate labeling around cell bodies and proximal portions of dendrites, whereas VC5.1 gave a more homogeneous labeling, which extended further out along the dendritic shafts. We cannot yet exclude the possibility that this difference was also related to the separate subclasses of the 2 antibodies. Clear variations in the staining patterns in retina and cerebellum, however, do suggest that different determinants were being recognized. More definitive evidence for the difference between the antigenic determinants was obtained from the biochemical studies. The 2 antibodies labeled separate molecular-weight bands on immunoblots of gels that were run at the same time, using the same fractions. VC1.1 recognized a major band of $M_{\mathrm{r}} 95,000-105,000$ and minor bands of $M_{\mathrm{r}} 145,000$ and $M_{\mathrm{r}} 170,000$. All 3 bands appeared to be integral membrane proteins since they were only 


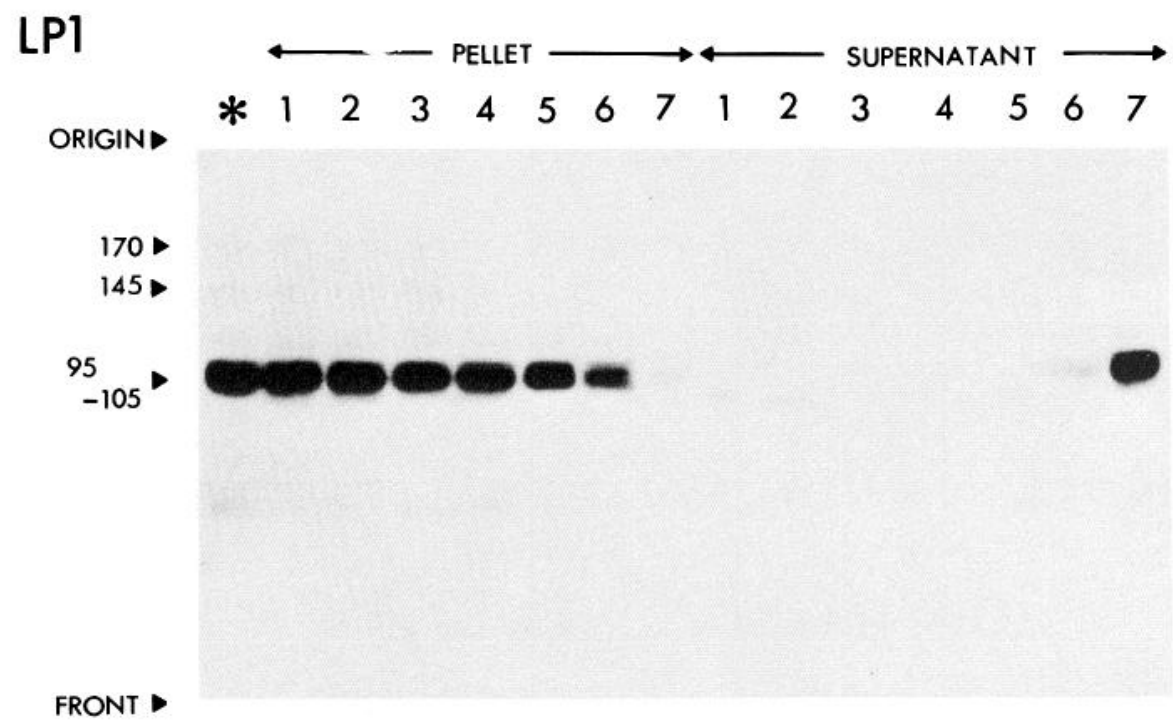

Figure 10. Effect of high ionic strength, low and high $\mathrm{pH}$, and detergents on the solubilization of VC1.1 antigens. Samples (1 mg protein) from the LP1 or P3 fraction were incubated in various solutions (1 ml), as indicated below. After the separation of soluble and particulate material by centrifugation, aliquots (30\% of total amount) of supernatant and pellet were analyzed by immunoblotting, using $\mathrm{VCl} .1$ antibody as described above. Top, LP1 fraction. Bottom, P3 fraction. Lane $1,10 \mathrm{~mm}$ Tris- $\mathrm{HCl}, \mathrm{pH} 8.0$; lane $2,1 \mathrm{M} \mathrm{NaCl}$ in Tris- $\mathrm{HCl}, \mathrm{pH} 8.0$; lane $3,3 \mathrm{M} \mathrm{NaCl}$ in Tris- $\mathrm{HCl}, \mathrm{pH} 8.0$; lane $4,10 \mathrm{~mm}$ Tris- $\mathrm{HCl}, \mathrm{pH} 3.0$; lane $5,10 \mathrm{~mm}$ Tris-HCl, pH 11.5; lane 6, 3\% Triton $\mathrm{X}-100$ in $10 \mathrm{~mm}$ Tris- $\mathrm{HCl}$, pH 8.0; lane $7,2 \%$ deoxycholate in $10 \mathrm{~mm}$ Tris- $\mathrm{HCl}$, pH 8.0. Asterisk represents starting material before the incubation.

P3

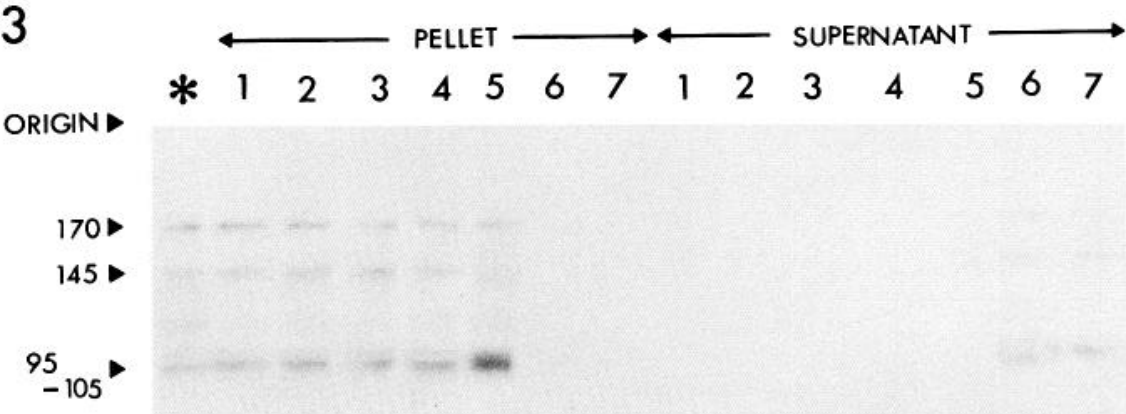

extracted from the membrane by detergent and not by highionic-strength buffer or low or high $\mathrm{pH}$. The molecular-weight range of the major band suggests that it may be glycosylated and thus a cell-surface molecule. This band was most prevalent in the synaptosomal plasma membrane fraction (LP1), whereas the other bands were more prevalent in the P3 and LP2 fractions. The relationship between the 3 bands and the significance of the different subcellular localization must await a more detailed characterization of the respective molecules.

VC5.1 recognized 2 polypeptides, of $M_{\mathrm{r}} 97,000$ and $M_{\mathrm{r}}$ 150,000 . To detect these bands on the immunoblots it was necessary to load over twice as much protein as was necessary for VC1.1. The 2 VC5.1-immunoreactive bands were preferentially localized in the soluble and microsomal fractions. Most of the microsomal antigen could be released into soluble compartments by hypotonic lysis and was thus probably material trapped within resealed membrane vesicles. Since VC5.1 labeling outlined cells rather than giving a uniform cytoplasmic labeling, the antigen is unlikely to be evenly distributed through- out the cytoplasm. It is possible that the antigen is loosely associated with the plasma membrane and is released upon homogenization. Alternatively, the VC5.1 determinant may be carried on an extracellular molecule that is soluble in isotonic buffers. Several such molecules have been described in other species (Delpech and Halavent, 1981; Grumet et al., 1985; Kruse et al., 1985). None of them, however, has the same biochemical characteristics as VC5.1.

The similarity in labeling patterns given by antibodies VC1.1 and VC5.1 and the similarity of molecular weights on immunoblots is worth noting. The differences in tissue distribution and the clear-cut difference in subcellular distribution discussed above both eliminate the possibility that the 2 antibodies are recognizing the same epitope. The possibility that the 2 antibodies recognize separate forms of the same molecule is also unlikely, given the range of differences of the 2 determinants, although it cannot be entirely excluded at present.

In many CNS areas, the clearest labeling by both VC1.1 and VC5.1 antibodies was around cell bodies and the proximal por- 
tions of dendrites, but the antibodies also gave a less distinct labeling in some neuropil areas away from the cell bodies. There are 2 possible explanations for the observed labeling patterns. One explanation of the neuropil immunoreactivity is that the antigens are expressed on postsynaptic cells and their distal dendrites. For example, the small circles of label in Figure $6 G$ probably represent dendrites cut in cross section. The more diffuse neuropil labeling might represent the finer extensions of dendritic processes that cannot be individually resolved with the immunofluorescence methods used. The clearest example of this is the labeling of retina given by $\mathrm{VCl} 1$, in which horizontal and amacrine cell bodies and their processes in the inner and outer plexiform layers were labeled.

The other explanation is that the labeling represents the presynaptic elements of a particular synaptic input, the bulk of which is concentrated around the cell bodies, but some of which is located on more distal portions of dendrites. A number of inhibitory neurons are known to make Gray's type II symmetrical contacts, which are concentrated in the vicinity of the cell body and proximal dendrites of visual cortical cells (LeVay, 1973; Houser et al., 1984). This would suggest that the labeled presynaptic elements in area 17 are part of an inhibitory circuit. It is not yet clear whether such an explanation is consistent with the labeling patterns of either antibody in the other regions of CNS.

Three other antibodies that also outline highly restricted subpopulations of neurons in the mammalian CNS have been described. One of these, Tor 23, generated against Torpedo electric organ synaptosomes, outlined a small subpopulation of neurons in rat cerebral cortex in a manner similar to that of VC1.1 and VC5.1 (Kushner, 1984). The molecule recognized by this antibody, however, migrated as a single band of $M_{\mathrm{r}} 180,000$ in SDS-polyacrylamide gels (Kushner and Stephenson, 1983; Kushner, 1984). An antiserum against an extracellular matrix glycoprotein called hyaluronectin outlined approximately $10 \%$ of the neurons in a number of rat brain regions, including the cerebral cortex (Delpech et al., 1982). Hyaluronectin from human brain was composed of 2 forms with molecular weights of 66,000 and of 100,000 , as determined by gel-permeation chromatography (Delpech, 1982). An antibody raised against cat spinal cord, Cat301, preferentially labeled subpopulations of neurons in area 17 of the cat and monkey, as well as subpopulations in a variety of other CNS regions. Cat301-positive cells in visual cortex and lateral geniculate nucleus (LGN) corresponded to morphologically distinct types of neurons that shared the common feature of belonging to the $\mathrm{Y}$-cell pathway (Hendry et al., 1984a). The Cat301 antibody shows several differences from and similarities to antibodies VC1.1 and VC5.1 at the cellular level. All 3 antibodies label structures at the surface of neuronal cell bodies and proximal dendrites, but not axons. Both VC1.1 and Cat301 have an irregular lattice-like distribution of binding sites across cell surfaces, which extends from the surface of the stained cells into surrounding neuropil.

Cat301 immunoreactivity in different regions of the cat visual system clearly differs from that of either VC1.1 or VC5.1. In area $17, \mathrm{VC} 1.1$ and VC5.1 immunoreactivity is restricted to nonpyramidal neurons in layers 4,5 , and 6, whereas Cat 301 stains subsets of both pyramidal and nonpyramidal neurons in layers 2, 3, 4A, 5, and 6 (MacAvoy et al., 1985). It is possible that a subset of cortical nonpyramidal neurons may share all 3 determinants, although double-labeling studies would be needed to confirm this. In the lateral geniculate nucleus, Cat301 staining was strong, whereas VC1.1 and VC5.1 immunoreactivity was not detectable (Hockfield et al., 1983). Finally, in the retina, VC1.1 and VC5.1 immunoreactivity is strong (although each labels different structures), whereas Cat301 immunoreactivity has not been detected. In other regions of the CNS, VCl.1 and VC5.1 show interesting similarities to and differences from Cat 301 . In the cerebellum, VC5.1 labeled the Lugaro cells, a rare neuronal cell population; basket cell terminals around Purkinje cells; and an occasional Golgi cell. Cat301 labeled only the Lugaro cells. All 3 antibodies showed similar intense labeling around subsets of motor neurons in the ventral horn of the spinal cord.

The subsets of neurons immunoreactive to antibodies VC1.1 and VC5.1 seem not to correspond to any subpopulations of cortical neurons so far identified by conventional anatomical methods or by immunocytochemical localization of neuroactive substances. On the basis of the dendritic staining patterns, these neurons are clearly nonpyramidal and possess features of multipolar and bitufted (see Fig. $4 B$ ) varieties of interneurons previously described using other methods (Lund et al., 1979; Somogyi, 1979; Fairen and Valverde, 1980; Peters and Regidor, 1981; Meyer, 1983). The lack of clear axonal labeling given by either antibody has not allowed us to use axonal morphology as a further criterion for identifying the morphological class labeled. It is known that some nonpyramidal neurons in all layers of mammalian visual cortex contain GABA and its synthetic enzyme glutamic acid decarboxylase (Ribak, 1978; Hendrickson et al., 1981; Freund et al., 1983; Hendry et al., 1984b; Houser et al., 1984; Otterson and Storm-Mathisen, 1984; Somogyi et al., 1984; Lin et al., 1986). The morphology and distribution of subpopulations of cortical neurons have also been detected by antisera against particular neuropeptides (Hendry et al., 1984b, c; Demeulemeester et al., 1985; Lin et al., 1986). Most of these subpopulations occur throughout all cortical layers but differ in relative frequencies within various layers. For example, cholecystokinin-immunoreactive cells occur chiefly in layers 1 and $2+3$, whereas somatostatin-immunoreactive cells occur mainly in laycrs 2 , 3 and 6 (Demculcmecster ct al., 1985). Colocalization of GABA and several neuropeptides has defined smaller subpopulations of neurons (Hendry et al., 1984b; Somogyi et al., 1984), but none of these has the same distribution as that of VC1.1- or VC5.1-labeled cells. Preliminary results suggest that most, if not all, of the layer 4,5 , and 6 cells outlined by VC1.1 also contain GABA (Naegele et al., 1986). It seems likely that VC1.1 and VC5.1 mark a subpopulation, or subpopulations, of GABAergic cells that has not been previously defined by GABA-neuropeptide phenotype.

In summary, we have produced immunological reagents that, in cat visual cortex, define molecules restricted to a previously unrecognized subclass of neurons. By using these reagents in combination with other forms of analysis, it will be possible to determine whether the molecules we have defined are part of a particular functional circuit and whether they play any role in the interactions necessary for setting up such circuits.

\section{References}

Akagawa, K., and C. J. Barnstable (1986) Identification and characterization of cell types in monolayer cultures of rat retina using monoclonal antibodies. Brain Res. 383: 110-120.

Arimatsu, Y., J. R. Naegele, and C. J. Barnstable (1985) Different structures in cat visual cortex revealed by monoclonal antibodies. Soc. Neurosci. Abstr. 11: 225. 
Barnstable, C. J. (1980) Monoclonal antibodies which recognize different cell types in the rat retina. Nature (Lond.) 286: 231-235:

Barnstable, C. J. (1982) Immunological studies of the retina. In $\mathrm{Neu}$ roimmunology, J. Brockes, ed., pp. 187-213, Plenum, New York.

Barnstable, C. J. (1985) Monoclonal antibodies as molecular probes of the nervous system. In Hvbridoma Technology in the Biosciences and Medicine, T. Springer, ed., pp. 269-289, Plenum, New York.

Barnstable, C. J., K. Akagawa, R. Hofstein, and J. P. Horn (1983) Monoclonal antibodies that label discrete cell types in the mammalian nervous system. Cold Spring Harbor Symp. Quant. Biol. 48: 863876.

Barnstable, C. J., R. Hofstein, and K. Akagawa (1985) A marker of early amacrine cell development in rat retina. Dev. Brain Res. 20: 286-290.

Baughman, R. W., and C. D. Gilbert (1981) Aspartate and glutamate as possible neurotransmitters in the visual cortex. J. Neurosci. 1:427439.

Delpech, A., N. Girard, and B. Delpech (1982) Localization of hyaluronectin in the nervous system. Brain Res. 245: 251-257.

Delpech, B. (1982) Immunochemical characterization of the hyaluronic acid-hyaluronectin interaction. J. Neurochem. 38: 978-984.

Delpech, B. C., and C. Halavent (1981) Characterization and purification from human brain of a hyaluronic acid binding glycoprotein: Hyaluronectin. J. Neurochem. 36: 855-859.

Demeulemeester, H., F. Vandesande, and G. A. Orban (1985) Immunocytochcmical localization of somatostatin and cholccystokinin in the cat visual cortex. Brain Res. 332: 361-364.

Emson, P. C., and S. P. Hunt (1984) Peptide-containing neurons of the cerebral cortex. In Cerebral Cortex, Vol. 2: Functional Properties of Cortical Cells, E. G. Jones and A. Peters, eds., pp. 145-169, Plenum, New York.

Fairen, A., and F. Valverde (1980) A specialized type of neuron in the visual cortex of cat. A Golgi study of chandelier cells. J. Comp. Neurol. 194: 761-779.

Fekete, D. M., and C. J. Barnstable (1983) The subcellular localisation of rat photoreceptor antigens. J. Neurocytol. 12: 785-803.

Freund, T. F., K. A. C. Martin, A. D. Smith, and P. Somogyi (1983) Glutamate decarboxylase-immunoreactive terminals of Golgi-impregnated axo-axonic cells and of presumed basket cells in synaptic contact with pyramidal neurons of the cat's visual cortex. J. Comp. Neurol. 221: 263-278.

Gilbert, C. D., and T. N. Wiesel (1979) Morphology and intracortical projections of functionally identified neurones in cat visual cortex. Nature (Lond.) 280: 120-125.

Grumet, M., S. Hoffman, K. L. Crossin, and G. M. Edelman (1985) Cytotactin, an extracellular matrix protein of neural and non-neural tissues that mediates glia-neuron interaction. Proc. Natl. Acad. Sci. USA 82: 8075-8079.

Hawkes, R., E. Niday, and A. Matus (1982) Monoclonal antibodies identify novel neural antigens. Proc. Natl. Acad. Sci. USA 79: 24102414.

Hendrickson, A. E., S. P. Hunt, and J.-Y. Wu (1981) Immunocytochemical localization of glutamic acid decarboxylase in monkey striate cortex. Nature (Lond.) 292: 605-607.

Hendry, S. H. C., S. Hockfield, E. G. Jones, and R. McKay (1984a) Monoclonal antibody that identifies subsets of neurones in the central visual system of monkey and cat. Nature (Lond.) 307: 267-269.

Hendry, S. H. C., E. G. Jones, J. DeFelipe, D. Schmechel, C. Brandon, and P. C. Emson (1984b) Neuropeptide-containing neurons of the cerebral cortex are also GABAergic. Proc. Natl. Acad. Sci. USA 81 : 6526-6530.

Hendry, S. H. C., E. G. Jones, and P. C. Emson (1984c) Morphology, distribution and synaptic relations of somatostatin- and neuropeptide Y-immunoreactive neurons in rat and monkey neocortex. J. Neurosci. 4: $2497-2517$

Hockfield, S., and R. D. G. McKay (1983) A surface antigen expressed by a subset of neurons in the vertebrate central nervous system. Proc. Natl. Acad. Sci. USA 80: 5758-5761.

Hockfield, S., R. D. McKay, S. H. C. Hendry, and E. G. Jones (1983) A surface antigen that identifies ocular dominance columns in the visual cortex and laminar features of the lateral geniculate nucleus. Cold Spring Harbor Symp. Quant. Biol. 48: 877-890.

Hökfelt, T., and A. Ljungdahl (1972) Autoradiographic identification of cerebral and cerebellar cortical neurons accumulating labeled gamma-aminobutyric acid ( $\left.{ }^{3} \mathrm{H}-\mathrm{GABA}\right)$. Exp. Brain Res. 14: 354-362.
Houser, C. R., S. H. C. Hendry, E. G. Jones, and J. E. Vaughn (1983) Morphological diversity of immunocytochemically identified GABA neurons in the monkey sensory-motor cortex. J. Neurocytol. 12:617638.

Houser, C. R., J. E. Vaughn, S. H. C. Hendry, E. G. Jones, and A. Peters (1984) GABA neurons in the cerebral cortex. In Cerebral Cortex Vol. 2: Functional Properties of Cortical Cells, E. G. Jones and A. Peters, eds., pp. 63-89, Plenum, New York.

Huttner, W. B., W. Schiebler, P. Greengard, and P. De Camilli (1983) Synapsin I (protein I), a nerve terminal-specific phosphoprotein. III. Its association with synaptic vesicles studied in a highly purified synaptic vesicle preparation. J. Cell Biol, 96: 1374-1388.

Iversen, L. L., and F. E. Bloom (1972) Studies of the uptake of ${ }^{3} \mathrm{H}$ glycine in slices and homogenates of rat brain and spinal cord by electron microscopic autoradiography. Brain Res. 41: 131-143.

Jahn, R., W. Schiebler, C. Ouimet, and P. Greengard (1985) A 38,000dalton membrane protein (p38) present in synaptic vesicles. Proc. Natl. Acad. Sci. USA 82: 4137-4141.

Kelly, J. P., and D. C. Van Essen (1974) Cell structure and function in the visual cortex of the cat. J. Physiol. 328: 515-547.

Köhler, G., and C. Milstein (1975) Continuous cultures of fused cells secreting antibody of predefined specificity. Nature (Lond.) 256: $495-$ 496.

Kruse, J., G. Keilhauer, A. Faissner, R. Timple, and M. Schachner (1985) The J1 glycoprotein: A novel nervous system cell adhesion molecule of the L2/HNK-1 family. Nature (Lond.) 316: 146-148.

Kushner, P. D. (1984) A library of monoclonal antibodies to Torpedo cholinergic synaptosomes. J. Neurochem 43: 775-786.

Kushner, P. D., and D. T. Stephenson (1983) A Torpedo monoclonal antibody that defines a subset of mammalian neurons. Soc. Neurosci. Abstr. 9: 758 .

Laemmli, U. K. (1970) Cleavage of structural proteins during the assembly of the head of bacteriophage T4. Nature (Lond.) 227:680685

LeVay, S. (1973) Synaptic patterns in the visual cortex of the cat and monkey. Electron microscopy of Golgi preparations. J. Comp. Neurol. 150: 53-86.

Levitt, P. (1984) A monoclonal antibody to limbic system neurons. Science 223: 299-301.

Lin, C. S., M. J. Friedlander, and S. M. Sherman (1979) Morphology of physiologically identified neurons in the visual cortex of the cat. Brain Res. 172: 344-348.

Lin, C. S., S. M. Lu, and D. E. Schmechel (1986) Glutamic acid decarboxylase and somatostatin immunoreactivities in rat visual cortex. J. Comp. Neurol. 244: 369-383.

Lowry, O. H., N. J. Rosebrough, A. L. Farr, and R. J. Randall (1951) Protein measurement with Folin phenol reagent. J. Biol. Chem. 193: 265-275.

Lund, J. S., G. H. Henry, C. L. Macqueen, and A. R. Harvey (1979) Anatomical organization of the primary visual cortex (area 17) of the cat. A comparison with area 17 of the macaque monkey. J. Comp. Neurol. 184: 599-618.

MacAvoy M. G.. S. Hockfield, and M. Sur (1985) Development of antigen expression in a possible $\mathrm{Y}$-cell pathway through the cat lateral geniculate nucleus and visual cortex. Soc. Neurosci. Abstr. 11: 224

McKay, R. D. G., and S. J. Hockfield (1982) Monoclonal antibodies distinguish antigenically discrete neuronal types in the vertebrate central nervous system. Proc. Natl. Acad. Sci. USA 79: 6747-6751.

Meyer, G. (1983) Axonal patterns and topography of short-axon neurons in visual areas 17, 18, and 19 of the cat. J. Comp. Neurol. 220: 405-438.

Naegele, J., Y. Arimatsu, and C. J. Barnstable (1986) Molecular markers distinguish a subpopulation of GABAergic neurons in middle and deep layers of cat visual cortex. Soc. Neurosci. Abstr. 12: 582.

Neal, M. J., and L. L. Iversen (1969) Subcellular distribution of endogenous and $\left[{ }^{3} \mathrm{H}\right]-\gamma$-aminobutyric acid in rat cerebral cortex. J. Neurochem. 16: 1245-1252.

Otsuka, R., and R. Hassler (1962) Uber Aufbau und Gliederung der Corticalen Sehesphare bei der Katze. Arch. Psychiatr. Z. Neurol. 203: 212-234

Otterson, O. P., and J. Storm-Mathisen (1984) Glutamate and GABAcontaining neurons in the mouse and rat brain, as demonstrated with a new immunocytochemical technique. J. Comp. Neurol. 229: 374 393. 
Palay, S. L., and V. Chan-Palay (1973) The Cerebellar Cortex, Cytology and Organization, Springer, Berlin.

Parnavelas, J. G., and J. K. McDonald (1983) The cerebral cortex. In Chemical Neuroanatomy, P. C. Emson, ed., pp. 505-549, Raven, New York.

Peters, A., and E. G. Jones (eds.) (1984) Cerebral Cortex, Vol. 1: Cellular Components of the Cerebral Cortex, Plcnum, Ncw York.

Peters, A., and J. Regidor (1981) A reassessment of the forms of nonpyramidal neurons in area 17 of cat visual cortex. J. Comp. Neurol. 203: 685-716.

Price, D. J. (1985) Patterns of cytochrome oxidase activity in areas 17,18 , and 19 of the visual cortex of cats and kittens. Exp. Brain Res. 58: 125-133.

Ribak, C. E. (1978) Aspinous and sparsely-spinous stellate neurons in the visual cortex of rats contain glutamic acid decarboxylase. J. Neurocytol. 7: 461-478.

Somogyi, P. (1979) An interneurone making synapses specifically on the axon initial segment of pyramidal cells in the cerebral cortex of the cat. J. Physiol. (Lond.) 296: 18-19P.

Somogyi, P., A. J. Hodgson, and A. D. Smith (1979) An approach to tracing neuron networks in the cerebral cortex and basal ganglia. Combination of Golgi staining, retrograde transport of horseradish peroxidase and anterograde degeneration of synaptic boutons in the same material. Neuroscience 3: 1805-1852.

Somogyi, P., A. J. Hodgson, A. D. Smith, M. G. Nunzi, A. Gorio, and J.-Y. Wu (1984) Different populations of GABAergic neurons in the visual cortex and hippocampus of cat contain somatostatin- or cholecystokinin-immunoreactive material. J. Neurosci. 4: 2590-2603.

Sternberger, L. A., L. W. Harwell, and N. H. Sternberger (1982) Neurotypy: Regional individuality in rat brain detected by immunocytochemistry with monoclonal antibodies. Proc. Natl. Acad. Sci. USA 79: $1326-1330$.

Streit, P. (1984) Glutamate and aspartate as transmitter candidates for systems of the cerebral cortex. In Cerebral Cortex, Vol. 2: Functional Properties of Cortical Cells, E. G. Jones and A. Peters, eds., pp. 119-143, Plenum, New York.

Towbin, H., T. Stachelin, and J. Gordon (1979) Electrophoretic transfer of proteins from polyacrylamide gels to nitrocellulose sheets: Procedure and some applications. Proc. Natl. Acad. Sci. USA 76:43504354.

Valnes, K., and P. Brandtzaeg (1985) Retardation of immunofluorescence fading during microscopy. J. Histochem. Cytochem. 33: 755761 .

Wong-Riley, M. (1979) Changes in the visual system of monocularly sutured or enucleated cats demonstrable with cytochrome oxidase histochemistry. Brain Res. 171: 11-28.

Woud, J. N., L. Hudson, T. M. Jessell, and M. Yamamoto (1982) A monoclonal antibody defining antigenic determinant on subpopulations of mammalian neurons and Trypanosoma cruzi parasites. Nature (Lond.) 296: 34-38.

Zipser, B., and R. McKay (1981) Monoclonal antibodies distinguish identifiable neurones in the leech. Nature 289: 549-554. 